\title{
Fideikomisy familijne w Drugiej Rzeczypospolitej - główne postulaty badawcze
}

\author{
WPROWADZENIE \\ POJĘCIE I ISTOTA PRAWNA FIDEIKOMISU
}

W rzymskiej instytucji prawa spadkowego zwanej fideikomisem spadkodawca prosił tego, kto otrzymał cokolwiek ze spadku, aby przekazał z niego określone dobra osobie trzeciej. Nazwa tej instytucji pochodzi od formuły wyrażenia prośby wobec takiego „powiernika”: fidei tue committo. Szczególną formą fideikomisu był fideikomis uniwersalny, polegający na tym, że spadkodawca prosił swojego dziedzica o przekazanie całego spadku wskazanej osobie trzeciej (fideicommissum hereditatis). Do tej konstrukcji nawiązywała kultura prawna krajów europejskich we wczesnej nowożytności, kiedy w obliczu kryzysu stosunków lennych i przemian gospodarczych możnowładcze i szlacheckie rody szukały instrumentów prawnych ochrony swojej pozycji (splendor familiae). W feudalizmie gwarancją tej pozycji były oczywiście majątki ziemskie, stąd naturalne dążenie do zachowania ich integralności i zapewnienia przekazywania ich w stanie nienaruszonym przyszłym pokoleniom. Celem było zatem uniknięcie osłabiających ród rozdrobnień majątków (zwłaszcza na skutek dziedziczenia) lub nieodpowiedzialnego zarządzania majątkami (prowadzącego do ich alienacji i obciążania wbrew interesom rodu).

Pomimo rzymskich inspiracji między instytucją prawa rzymskiego określaną mianem fideikomisu a noszącymi nierzadko tę samą nazwę rozwiązaniami z okresu rozwiniętego feudalizmu występowały istotne różnice. Ponadto każda z odmian fideikomisów familijnych powstających w poszczególnych krajach Europy od XVI w. miała swoją specyfikę - zarówno w zakresie stosowanej terminologii prawnej, jak i konstrukcji prawnej. Inny charakter miały hiszpańskie mayorazgo, 
inny - fideikomisy i powiernictwa na terenie Rzeszy Niemieckiej, a jeszcze inny staropolskie ordynacje.

Konsekwencją tych różnic są trudności w prowadzeniu badań nad instytucjami fideikomisowymi na ziemiach polskich. W wyniku utraty niepodległości przez Rzeczpospolitą w XIX i początkach XX w. rozwijały się tu cztery (a wliczając $\mathrm{w}$ to prawo staropolskie, nawet pięć) odrębne systemy prawa cywilnego regulujące problematykę fideikomisów. Badania nad międzywojennymi losami tej instytucji wymagają zatem analizy komparatystycznej, co rodzi pewne problemy definicyjne i terminologiczne. Nawet samo nazewnictwo omawianej instytucji budzi kontrowersje. Artykuł 1 ustawy o znoszeniu ordynacyj rodowych przywoływał liczne pojęcia synonimiczne na określenie omawianej instytucji, odnoszące się zarówno do jej alternatywnych nazw („ordynacja”, „fideikomis”, „powiernictwo” oraz „dobra zapowiednie” i ,czasowo zapowiednie”), jak i do modeli sukcesji (,seniorat”, „majorat”, „minorat”). Za najlepsze rozwiązanie uznać należy odwołanie do klasycznego, rzymskiego pojęcia „fideikomisu”, przy doprecyzowaniu charakteru feudalnego przez dodanie przymiotnika „familijny”. Pojęcie to ma szczególne znaczenie dla niżej opisanej planowanej analizy komparatystycznej. Podobnych problemów terminologicznych przysparza nazewnictwo innych kwestii związanych z konstrukcją prawną fideikomisu. Osoba obejmująca całość dóbr fideikomisowych jest najczęściej określana w literaturze mianem ,powiernika fideikomisu” i zwrot ten należy uznać za najwłaściwszy w świetle opisywanych badań. Za nie dość precyzyjne uznano zaś określenie „posiadacz dóbr”, którym posługiwano się w art. 2 ustawy z 13 lipca 1939 r. o znoszeniu ordynacyj rodowych ${ }^{1}$. Niewłaściwa wydaje się też nazwa „ordynat” - adekwatna jedynie w odniesieniu do ordynacji staropolskich, ewentualnie rosyjskich na ziemiach wschodnich. Za najlepszy na określenie członków rodu uprawnionych potencjalnie do objęcia dóbr fideikomisowych po aktualnym powierniku uznano - zgodnie z tradycją niemiecką i austriacką - termin „oczekiwacze”.

Również proponowane w polskim piśmiennictwie prawniczym (zwłaszcza okresu międzywojennego definicje fideikomisów co do zasady były formułowane w odniesieniu do konkretnych regulacji na gruncie jednego porządku prawnego ${ }^{3}$. Spośród prób ogólniejszych definicji odnoszących się do całego odrodzonego pań-

${ }^{1}$ Dz.U. Nr 63, poz. 417.

2 Jest to termin najczęściej spotykany w literaturze, choć ustawa z dnia 18 listopada $1921 \mathrm{r}$. o dobrach rodzinnych w b. dzielnicy pruskiej (Dz. U. Nr 100, poz. 715) powołuje synonimiczne pojęcie „ekspektantów”.

${ }^{3}$ Ciekawe zestawienie różnic konstrukcyjnych między poszczególnymi typami instytucji fideikomisowych we wszystkich dawnych dzielnicach II Rzeczpospolitej prezentuje hasło encyklopedyczne Ordynacje rodowe [w:] F. Zoll, J. Wasilkowski (red.), Encyklopedja podręczna prawa prywatnego: założona przez Henryka Konica, t. 2: Księgi wieczyste - ordynacje rodowe, Warszawa 1936, s. $1222-1241$. 
stwa polskiego na uwagę zasługuje ujęcie art. 1 ust. 2 ustawy o znoszeniu ordynacyj rodowych, zgodnie z którym fideikomisy rodzinne to „wszelkie rozporządzenia, mocą których określony majątek stanowi niezbywalną własność rodu i ma być zachowany dla wszystkich lub przynajmniej dla większej ilości przyszłych pokoleń, czy to przez ustanowienie na rzecz rodu własności zwierzchniej tego majątku, czy też przez ograniczenie właściciela w prawie rozporządzania tym majątkiem". Zwłaszcza ta druga definicja ma pewne zalety w kontekście ogólnej refleksji nad fideikomisami. Po pierwsze, jest to definicja legalna, zaczerpnięta bezpośrednio z ustawy uchwalonej przez Sejm w okresie Polski międzywojennej. Po drugie, jasno ukazuje ona cel - w postaci zachowania majątku dla przyszłych pokoleń danego rodu - jako element wyróżniający dla tej instytucji prawnej. Uwzględnia przy tym zarówno instytucje wieczyste, jak i czasowe (jeśli fideikomis miał trwać przez „większą ilość”, tj. co najmniej kilka, pokoleń). Po trzecie, ma szeroki zakres w sposób elastyczny regulując kwestię własności dóbr fideikomisowych, pozwala uwzględnić wszystkie możliwe formy fideikomisowe oraz różne ich rozumienie w doktrynach prawnych państw zaborczych. Odwołuje się bowiem nie tylko do konstrukcji feudalnej własności podzielonej, uznając cały ród za podmiot prawa własności (przyznając mu własność zwierzchnią, a contrario uznając ,powiernika” fideikomisu za właściciela użytkowego), lecz także ujmuje te konstrukcje, w których to ów „powiernik” ma status właściciela, ograniczonego jedynie istnieniem ograniczonych praw rzeczowych do majątku fideikomisowego ze strony innych członków rodu. Nawet tak ogólna definicja nie może być jednak uznana za w pełni adekwatną.

Pomimo wątpliwości definicyjnych oraz istotnych odrębności między konkretnymi typami fideikomisów występujących na gruncie poszczególnych porządków prawnych państw europejskich należy uznać, że możemy mówić o jednej instytucji prawnej. Wyróżniał ją pewien zestaw cech, które - naszym zdaniem - można ująć w kilku punktach.

Po pierwsze, wspólny element fideikomisów stanowił główny cel powołania tej instytucji, tj. zachowanie majątku rodowego w stanie nienaruszonym dla kolejnych pokoleń rodu i zapewnienie w ten sposób odpowiedniego statusu społecznego danej familii.

Pod drugie, w poszczególnych krajach obowiązywała specyficzna procedura i forma tworzenia fideikomisów. Powstawały one na mocy czynności prawnej fundatora, często wymagającej zgody władzy państwowej, a skutki prawne takiej czynności co do zasady mógł odwrócić jedynie sam fundator. Oznaczało to najczęściej, że po jego śmierci nie było możliwości zmiany charakteru dóbr fideikomisowych przez ich aktualnego powiernika. Takie zmiany albo były zakazane, albo wymagały konsensu wszystkich członków rodu, a niekiedy nawet zgody władzy państwowej. 
Po trzecie, istotę fideikomisu stanowiło przyznanie całości dóbr fideikomisowych jednej osobie (powiernikowi fideikomisu), której nie przysługiwała pełnia uprawnień właścicielskich. W tym zakresie odwoływano się do różnych konstrukcji prawnych: własności podzielonej (w której powiernik byłby tylko właścicielem użytkowym, przy własności zwierzchniej zarezerwowanej dla rodu), uznawania praw powiernika za ograniczone prawo rzeczowe, a nawet za prawo własności, obciążone tylko ograniczonymi prawami rzeczowymi pozostałych członków rodu ${ }^{4}$.

Po czwarte, dobra fideikomisowe były wyłączane z porządku spadkobrania tak ustawowego, jak i testamentowego - co oznaczało, że przejęcie tych dóbr odbywało się na zupełnie innych zasadach, wynikających z aktu fundacyjnego, niż dziedziczenie po powierniku jako osobie fizycznej ${ }^{5}$.

Po piąte, cechę wspólną feudalnych fideikomisów familijnych stanowiły ograniczenia możliwości zbywania i obciążania majątku. Mogły one mieć różny charakter i stopień - od całkowitego zakazu alienacji i obciążania majątku po bardziej elastyczne rozwiązania.

\section{STAN BADAŃ}

Zagadnienie fideikomisów familijnych stało się przedmiotem wielu dociekań naukowych i cennych opracowań. Instytucji fideikomisu uniwersalnego w klasycznym prawie rzymskim kompleksową monografię poświęcił Franciszek

${ }^{4}$ Takie rozumienie fideikomisu pozwala objąć wszystkie konstrukcje tego typu, niezależnie od doktrynalnych rozważań o własności podzielonej, zwłaszcza własności zwierzchniej fideikomisu (tj. czy przysługuje ona abstrakcyjnie pojmowanej „,rodzinie”, czy jej żyjącym członkom). Por. wnikliwą analizę teorii na gruncie prawa pruskiego: K. Sójka-Zielińska, Fideikomisy familijne w prawie pruskim (w XIX i pocz. XX w.), Warszawa 1962, s. 72-79 oraz rozważania ogólne: Ordynacje rodowe, [w:] F. Zoll, J. Wasilkowski (red.), Encyklopedia podręczna..., s. 1229.

${ }^{5}$ Różnice dotyczyły całej koncepcji sukcesji, powiernik był bowiem następcą prawnym nie poprzedniego powiernika, ale samego założyciela ordynacji. Por. wnikliwe uzasadnienie E. Tilla, Prawo prywatne austriackie, t. VI: Wykład prawa spadkowego, Lwów 1904, s. 492-494. Jest to kluczowy element samej konstrukcji fideikomisu familijnego, a niezrozumienie tego mechanizmu może prowadzić do niezrozumienia samej istoty instytucji. Tak np. w pracy J. Kłoczka, Ordynacje rodowe w Rzeczypospolitej. Powstanie i funkcjonowanie w okresie staropolskim [w:] D. Kuźmina, R. Lolo (red.), Szlachta polska i jej dziedzictwo, Warszawa 2013, s. 78, który stwierdza: „wspólną cechą ordynacji [...] było zabezpieczenie dla spadkobierców [...] majątku ruchomego i nieruchomego, wyłączonego jednocześnie ze spadkobrania ustawowego". W konsekwencji takiego stwierdzenia w kategorii fideikomisów autor ten ujmuje dokonywane za zgodą monarchy w XIV i XV w. zupełne pozbawianie kobiet praw do dziedziczenia dóbr nieruchomych. Ibidem, s. 78-80. Nie były to jednak akty ustanawiające fideikomisy właśnie dlatego, że brak w nich rzymskiego elementu „,podstawienia” powiernika, czyli „,powierzenia” mu dóbr, by mógł je przekazać przyszłym pokoleniom rodu. $Z$ tego zresztą wynikała konstatowana przez autora „nietrwałość” tych wczesnych instytucji, były to bowiem w założeniu raczej doraźne środki zaradcze, mające zapobiec oderwaniu i utracie części dóbr. 
Longschamps de Bérier, podsumowując wyniki swych badań uwagami de lege ferend $a^{6}$. Odrodzenie idei fideikomisu jako „powierznictwa” familijnego, które nastąpiło w XVI w. najpierw w Kastylii, a potem we Włoszech i Francji, było oczywiście przedmiotem analiz w literaturze historycznej tych państw. W polskiej historiografii ,ordynacje” zakładane w czasach Rzeczypospolitej Obojga Narodów w XVI-XVIII w. nie były przedmiotem szczególnego zainteresowania, doczekały się jedynie syntetycznych uwag Przemysława Dąbkowskiego oraz znakomitej analizy pióra Aleksandra Mełenia ${ }^{7}$. Od strony historycznej zbadali je natomiast i opisali w odrębnych szkicach Teresa Zielińska i Jarosław Kłoczek ${ }^{8}$. Losy poszczególnych ordynacji, np. Zamoyskiej przedstawiono ponadto w szczegółowych opracowaniach ${ }^{9}$.

W odniesieniu do XIX i XX w. fideikomisy familijne w porządkach prawnych państw zaborczych były przedmiotem zainteresowań prawników z pierwszej połowy XX w., w mniejszym stopniu historyków i historyków prawa po II wojnie światowej. Fideikomisy familijne w prawie pruskim doczekały się - zarówno w zakresie prezentacji stanu formalnoprawnego, jak i szerokiej prezentacji poglądów dogmatycznych i teoretycznych, z uwzględnieniem politycznego i społecznego kontekstu - wnikliwego studium Katarzyny Sójki-Zielińskiej ${ }^{10}$. Dorobek dotyczący obszaru obowiązywania austriackiego ABGB to przede wszystkim przedwojenne ujęcia syntetyczno-komentarzowe pióra: Ignacego Szczęsnego Czemeryńskiego, Ernesta Tilla, Stanisława Wróblewskiego i Fryderyka Zolla ${ }^{11}$. Określenie sytuacji fideikomisów na ziemiach polskich pod zaborami pruskim i austriackim oraz w dzielnicach powstałych tam po odzyskaniu niepodległości umożliwia także

${ }^{6}$ F. Longschamps de Bérier, O elastyczność prawa spadkowego. Fideikomis uniwersalny w klasycznym prawie rzymskim, Warszawa 2006.

7 P. Dąbkowski, Prawo prywatne polskie, t. I, Lwów 1919, s. 36-41; A. Mełeń, Ordynacje w dawnej Polsce, „Pamiętnik Historyczno-Prawny” Lwów 1929, t. VII, z. 2.

${ }_{8}$ J. Kłoczek, Ordynacje rodowe w Rzeczypospolitej...; T. Zielińska, Ordynacje w dawnej Polsce, ,Przegląd Historyczny” 1977, t. 68, nr 1.

${ }_{9}$ M. Groszkowski, Sprawa rywalizacji o Ordynacje Zamoyska na pierwszym sejmie 1666 roku, „Meritum” 2017, t. IX; idem, Stosunek sejmików ziemi liwskiej i różańskiej do sprawy Ordynacji Zamojskiej w latach 1666-1676, „Rocznik Liwski” 2015, t. 8; R. Orłowski, Szkice z dziejów Ordynacji Zamoyskich w XVIII wieku, Zamość 2011; R. Szczygieł, Ordynacja Zamojska wobec prób lokacji ośrodków miejskich przy jej granicach w pierwszej połowie XVII w., „Studia Iuridica Lublinensia" 2016, t. XXV, nr 3.

${ }^{10}$ K. Sójka-Zielińska, Fideikomisy familijne..., passim.

${ }^{11}$ I. Czemeryński, Powszechne prawo prywatne austryjackie: dla użytku podręcznego, t. 1-2, Lwów 1861-1868, s. 425-437; Komentarz do \$§ 531-824 Austryackiego kodeksu cywilnego (prawo spadkowe), oprac. S. Wróblewski, Kraków 1904, s. 242-326; F. Zoll, Prawo cywilne opracowane głównie na podstawie przepisów obowiązujących w Małopolsce, t. III: Prawa rzeczowe i rzeczowym podobne, Poznań 1931, s. 10-14; E. Till, Prawo prywatne austriackie, s. 459-502. 
bogata literatura niemieckojęzyczna ${ }^{12}$. W odniesieniu do fideikomisów w Księstwie Warszawskim i Królestwie Polskim kilka studiów poświecono problematyce pokrewnych im donacji ${ }^{13}$. Pewne uwagi zawiera w tym zakresie także niewydana dotąd rozprawa doktorska Zbigniewa Filipiaka ${ }^{14}$. W okresie międzywojennym opublikowano kilka szkiców o problemie ordynacji i majątków rodowych na ziemiach wschodnich ${ }^{15}$. Na uwagę zasługują prace dotyczące losów poszczególnych rodów, które ustanawiały fideikomisy ${ }^{16}$.

${ }_{12}$ Zob. m.in. B. Bayer, Sukzession und Freiheit. Historische Voraussetzungen der rechtstheoretischen und rechtsphilosophischen Auseinandersetzungen um das Institut der Familienfideikomisse im 18 und 19 Jahrundert, Berlin 1991; J. Conrad, Die Familienfideikonisse in den östlichen Provinzen Preussens, Tübingen 1889; J. Eckert, Der Kampf um die Familienfideikomisse in Deutschland. Studien zum Absterben eines Rechtsinstitutes, Frankfurt am Main 1992; F. Kato, Das Preußische Fideikomiss. Studien zu zeiner nationalökonomischen Funktion im Übergang zum imperialistischen Kapitalismus, Frankfurt am Main 2017; W. Lewis, Das Recht Familienfideikomisses, Berlin 1868 (reprint: Aalen 1969); H. Ramdohr, Das Familienfideikommiß im Gebiete des preußischen Allgemeinen Landrechts, Berlin 1909; H.H. v. Schweinitz, Zum Fideikommißwesen der Gegenwart und Zukunft. Eine Betrachtung zu dem vorläufigen Entwurf eines Gesetzes über Familienfideikommisse, Berlin 1904; T. v. Tritt zu Stolz, Erbrechtlose Sondervermögen: über die Möglichkeiten fideikommiß ähnlicher Vermögensbindungen, Frankfurt am Main 1999.

${ }_{13}$ M. Senkowska-Gluck, Donacje napoleońskie w Księstwie Warszawskim. Studium historyczno-prawne, Wrocław 1948; B. Bornstein, Majoraty (donacje) w b. Królestwie Polskim, Warszawa 1922; J. Kaczkowski, Donacye w Królestwie Polskiem, Warszawa 1917; idem, Z powodu głosów o majoratach w Królestwie Polskim, „Gazeta Sądowa Warszawska” 1916, nr 17; J. Kukulski, Donacje po powstaniu styczniowym, „Acta Universitatis Lodziensis. Folia Historica” 1986, nr 24; idem, Donacje Paskiewiczowskie w okresie reform agrarnych, Kielce 1987; L.T., Majoraty w Królestwie Polskiem, „Gazeta Sądowa Warszawska” 1915, nr 24; idem, Odpowiedź na artykut „Z powodu głosów o majoratach w Królestwie Polskiem”, „Gazeta Sądowa Warszawska” 1916, nr 17.

${ }_{14}$ Z. Filipiak, Prawo własności nieruchomości w Księstwie Warszawskim i Królestwie Polskim doby konstytucyjnej, rozprawa doktorska napisana w Katedrze Powszechnej Historii Państwa i Prawa na Wydziale Prawa i Administracji UMK, pod kierunkiem dra hab. Andrzeja Gacy, prof. UMK, Toruń 2013.

${ }_{15}$ A. Bardzki, Majątki rodowe w województwach wschodnich, „Gazeta Sądowa Warszawska” 1928, nr 56; Z. Bossowski, Przedstawienie praw ordynata do majątku ordynackiego, „Gazeta Sądowa Warszawska” 1928, nr 57; S. Muzykant, Majątki rodowe w województwach wschodnich, „Gazeta Sądowa Warszawska” 1928, nr 56. Na osobne wyróżnienie zasługują uwagi komentarzowe polskich wydawców t. X cz. 1 Zwodu Praw - Prawo cywilne ziem wschodnich. T. X cz. 1 Zwodu Praw Rosyjskich. Tekst podtug wydania urzędowego z roku 1914, z uwzględnieniem zmian, wprowadzonych przez ustawodawcę polskiego, oraz ustawy związkowe tudzież judykatura Sądu Najwyższego i b. Senatu Rosyjskiego, tłum. i oprac. Z. Rymowicz, W. Świecicki, t. 1, Warszawa 1932-1933.

16 Por. zwłaszcza G. Madej, Bielska linia książęcego rodu Sułkowskich (1786-1918), Bielsko-Biała 2018; S. Górzyński, J. Grala, W. Piwkowski, V. Urbaniak, T. Zielińska, Radziwiłłowie herbu Trąby, Warszawa 1996, http://ww.dig.com.pl/pdf/Radziwillowie.pdf [dostęp: 30.04.2019]; Z. Rączka, Bielska linia Sułkowskich i jej archiwum, „Archeion” 1984, nr 77, s. 135-153, R. Kąsinowska, Pałac w Jarocinie: dzieje rezydencji i jej właścicieli, Jarocin 2012; S. Karwowski, Historia rodu Leszczyców z Radolina Radolińskich, Jarocin 2010, K. Myśliński, Ordynacja Myszkowskich w rękach rodu Wielopolskich 1727-1945; E. Wierzbicka, Wielopolscy: dzieje awansu spolecznego oraz 
Raczej niewiele studiów ma charakter porównawczy, choć analizują różne konstrukcje fideikomisowe we wszystkich dzielnicowych porządkach prawnych Drugiej Rzeczypospolitej. O kwestiach gospodarczych związanych z fideikomisami w całym odrodzonym państwie pisał zwłaszcza Marian Kozaczka ${ }^{17}$, ale także inni autorzy ${ }^{18}$. W aspektach prawnych $\mathrm{w}$ zasadzie jedyna próba porównawczego spojrzenia na fideikomisy została zamieszczona w Encyklopedii podręcznej prawa prywatnego redagowanej przez Henryka Konica ${ }^{19}$. Kilka prac w okresie międzywojennym poświęcono dyskusji nad wspomnianą już ustawą znoszącą ordynacje rodowe uchwaloną ostatecznie w 1939 r. ${ }^{20}$ Należy jednak stwierdzić, że problematyka prawnych aspektów funkcjonowania fideikomisów familijnych po odzyskaniu przez Polskę niepodległości nie została dotąd szerzej opracowana naukowo z wykorzystaniem dorobku praktyki. Z tych względów za pożądane trzeba uznać podjęcie badań w tym temacie. Zadania tego podjął się zespół naukowy pod kierownictwem prof. Zbigniewa Naworskiego, planując przeprowadzenie szeroko zakreślonych badań nad fideikomisami familijnymi w Drugiej Rzeczypospolitej, przede wszystkim w świetle orzecznictwa sądów cywilnych ${ }^{21}$.

utrwalenia pozycji rodziny od połowy XVII do schyłku XVIII wieku, Lublin 2017; T. Włodarska, B. Spyra, Historia Archiwum Książąt Pszczyńskich, „Archeion” 1962, nr 37, s. 191-206.

${ }_{17} \mathrm{Na}$ wyróżnienie zasługuje oparta na obszernej kwerendzie archiwalnej monografia M. Kozaczki, Gospodarka ordynacji rodowych w Polsce 1918-1939, Rzeszów 1996. Zob. także inne publikacje tego autora poświęcone głównie losom gospodarczym konkretnych fideikomisów: Ordynacja Zamoyska 1918-1945, Lublin 2003; Ordynacja ołycka w latach 1918-1939, „Przegląd Przemyski” 2005, t. XL, s. 83-94; Ordynacja nieświeska w latach 1918-1924, „Kwartalnik Historyczny” 1995, t. CII, z. 2, s. 27-42; Gospodarka leśna ordynacji zamoyskiej (1918-1939), „Kwartalnik Historyczny" 2002, t. CIX, z. 2, s. 61-75.

${ }_{18}$ M. Drożdż-Szczybura, Ordynacje rodowe $w$ XIX $i$ w pierwszej połowie XX w. Wielkie posiadlości ziemskie i ich ksztalt prawno-organizacyjny w Polsce porozbiorowej na przykładzie ordynacji tańcuckiej. Pomoc dydaktyczna, Kraków 1998; A. Koprukowniak, Likwidacja serwitutów w Ordynacji Zamoyskiej (1920-1932), „Rocznik Lubelski” 1960, nr 3, s. 225-240; Z. Mazurczak, Walka chtopów Ordynacji Zamojskiej o prawa serwitutowe w końcu XIX wieku, „Annales Universitatis Mariae Curie-Skłodowska. Sectio F, Nauki Filozoficzne i Humanistyczne” 1957, nr 12, s. 197-220; J. Pencak, Papiernia Ordynacji Zamojskiej w Hamerni, „Archeion” 1958, t. 28, s. 159-178. Ogólne studium porównawcze jeszcze przed odzyskaniem niepodległości opracował K. Kościński, Polskie ordynacye i związi rodzinne, ze szczególnym uwzględnieniem ordynacyi Książat Sulkowskich, Poznań 1906.

${ }_{19}$ Ordynacje rodowe [w:] F. Zoll, J. Wasilkowski (red.), Encyklopedia podręczna..., s. 12221244.

20 [I. Muzykant], Projekt ustawy o zniesieniu ordynacji, „Przegląd Notarialny” 1936, t. XIV, nr 7, s. 23; [E. Wnedorff], Znoszenie ordynacji, „Przegląd Notarialny” 1939, t. XVII, nr 15-16, s. 339 .

${ }^{21}$ Zespołowy projekt badawczy pt. „Fideikomisy familijne w Drugiej Rzeczypospolitej w świetle orzecznictwa sądów cywilnych. Dzieje funkcjonowania feudalnej instytucji prawnej w obrocie prawnym państwa nowoczesnego", finansowany z Narodowego Centrum Nauki w ramach konkursu OPUS 14 (grant nr 2017/27/B/HS5/02679). W skład zespołu badawczego, oprócz dra hab. Z. Naworskiego, prof. UMK, wchodzą: dr Anna Moszyńska, dr Zbigniew Filipiak i dr Tomasz Kucharski. 


\section{CEL I ZAKRES PRAC BADAWCZYCH}

Zasadniczym celem badań jest określenie sposobu funkcjonowania instytucji feudalnego fideikomisu familijnego w praktyce obrotu prawnego państwa XX-wiecznego - Drugiej Rzeczypospolitej w latach 1918-1939.

Jeśli chodzi o zakres chronologiczny, to analiza obejmie cały międzywojenny okres funkcjonowania państwa polskiego, tj. lata 1918-1939. Datę początkową określa moment odrodzenia Polski po Wielkiej Wojnie, a datę końcową - przede wszystkim uchwalenie ustawy o znoszeniu ordynacyj rodowych w 1939 r. Dopełnieniem końca fideikomisów na ziemiach polskich stał się wybuch II wojny światowej, a następnie powstanie Polski Ludowej - państwa o zupełnie nowej formie i granicach, które programowo sprzeciwiało się wszelkim feudalnym i szlacheckim reliktom.

Przy określaniu ogólnych założeń projektu wątpliwości budziło uwzględnienie w badaniach dość nielicznych, ale specyficznych ordynacji powstałych w okresie staropolskim. Ostatecznie zdecydowano się włączyć je do analizy. Przesądziły o tym: ich rdzennie polski charakter, rola w życiu gospodarczym dwudziestolecia międzywojennego, a także wzgląd na kompletność i miarodajność ostatecznych wyników badań.

Kontrowersyjny problem stanowiło uwzględnienie sytuacji tzw. ziem wschodnich Drugiej Rzeczypospolitej, na których w zakresie prawa cywilnego obowiązywał przede wszystkim t. X, cz. 1 Zwodu Praw Cesarstwa Rosyjskiego. Są bowiem dwa przeciwwskazania do uwzględnienia tego problemu w założeniach badawczych: jeden natury merytorycznej, drugi - technicznej. Pierwszy, istotniejszy,-nakazywał ocenę rosyjskiej kodyfikacji cywilnej i zawartych w niej regulacji prawa rzeczowego i spadkowego pod względem ich jakości. Rozwiązania te były bardzo anachroniczne, zawierające wiele przeżytków z epoki feudalnej. Dlatego klasyczne ordynacje rodowe zostały na tym obszarze uregulowane odmiennie niż w pozostałych byłych zaborach. Uwzględnienie w analizie komparatystycznej anachronicznego prawa rzeczowego i spadkowego zawartego w Zwodzie Praw wydawało się więc ze wszech miar trudne. Drugi problem ma charakter bardziej pragmatyczny - obejmuje utrudnienia w prowadzeniu kwerendy na materiałach przechowywanych w dużej części poza granicami Polski, co wiąże się nie tylko ze znacznym zwiększeniem kosztów badań, ale także z obostrzeniami w dostępie do zagranicznych źródeł archiwalnych. O ujęciu fideikomisów regulowanych przepisami Zwodu Praw zdecydowała chęć zachowania integralności projektu badawczego - bez analizy stanu prawnego jednej z dzielnic porozbiorowych rezultaty badań byłyby niepełne. W konsekwencji tego konieczne będzie przeprowadzenie kwerendy w Litewskim Centralnym Archiwum Historycznym w Wilnie. 
Kwestią problematyczną było również uwzględnienie w badaniach przepisów dotyczących „majoratów” i „donacji” tymczasowych, tworzonych na terenie „guberni zachodnich” Imperium Rosyjskiego, czyli w byłym Królestwie Kongresowym. Stanowily one specyficzne formy dóbr fideikomisowych, przyznawanych $\mathrm{w}$ ramach nagrody carskim generałom za zasługi dla Imperium w dobie pacyfikacji polskich powstań narodowych: listopadowego i styczniowego. Notabene wzorowano je na donacjach napoleońskich, które trafiły do Księstwa Warszawskiego z Francji. Zostały one zniesione na terenie dawnego Królestwa Polskiego wraz z odrodzeniem się państwa polskiego na mocy ustawy z dnia 25 lipca 1919 r. $\mathrm{w}$ przedmiocie dóbr donacyjnych ${ }^{22}$. O uwzględnieniu tej kwestii w badaniach przesądziło pokrewieństwo konstrukcyjne między klasycznymi fideikomisami a donacjami (które w zasadzie przejawiały wszystkie wskazane na początku artykułu cechy konstrukcji fideikomisowych). Za ciekawy problem badawczy uznano przy tym sprawdzenie, czy funkcjonowanie i proces likwidacji tej unikatowej odmiany konstrukcji fideikomisowej pozostawiły ślady w orzecznictwie sądów odrodzonego w 1918 r. państwa polskiego.

Wątpliwości co do określenia obszaru badań dotyczyły także terenów wschodniej Galicji (okręg apelacji lwowskiej), na których obowiązywał austriacki kodeks cywilny. Na ostateczną decyzję o nieuwzględnieniu tego obszaru wpłynęły przede wszystkim założenia pragmatyczne oraz skomplikowana sytuacja geopolityczna Ukrainy. Ponadto materiał dla apelacji krakowskiej, zgromadzony w polskich archiwach, wydaje się w pełni wystarczający do zrealizowania założeń projektu.

\section{ZNACZENIE PROJEKTU}

Lepsze poznanie instytucji fideikomisów familijnych istniejących w Polsce od czasów staropolskich, a także pochodzących z porządków prawnych państw zaborczych może przyczynić się do całościowej oceny prawnych aspektów ich funkcjonowania z punktu widzenia praktyki orzeczniczej sądów cywilnych w Polsce międzywojennej. Analiza regulacji prawnych i wyroków sądowych w tym zakresie pozwoli na ukazanie przemian prawnych dokonujących się od drugiej połowy XIX w. do wybuchu II wojny światowej. Przykład fideikomisów znakomicie oddaje szerszy problem trwania w realiach XX-wiecznej kultury prawnej instytucji i rozwiązań prawnych z okresu feudalnego. Refleksja, w jaki sposób sędziowie interpretowali przepisy dotyczące fideikomisów - z którymi wiele

${ }^{22}$ Dz.U. Nr 72, poz. 423 zmienionej ustawą z dnia 26 października 1920 r. w sprawie zmiany art. 18 ustawy z dnia 25 lipca 1919 roku w przedmiocie dóbr donacyjnych, Dz. U. Nr 103, poz. 682. W kwestii sporu o zakres obowiązywania tej ustawy na ziemiach wschodnich zob. A. Bardzki, Majątki rodowe..., s. 342-343; S. Muzykant, Majątki rodowe..., s. 690-692. 
problemów interpretacyjnych mieli już wychowani na tradycji prawa rzymskiego juryści z okresu feudalnego - może stanowić element studium warsztatu prawniczego sędziów i przyczynić się do określenia znaczenia orzecznictwa sądowego w okresie międzywojennym.

$\mathrm{Na}$ tle przedstawionego zagadnienia wyłaniają się ciekawe wyzwania badawcze. Pierwszym z nich jest analiza sporów sądowych, których fideikomis lub jego powiernik byli stronami - głównie w sprawach związanych z funkcjonowaniem fideikomisu jako podmiotu prowadzącego działalność gospodarczą, zwłaszcza jako gospodarstwa rolnego. Były to sprawy dotyczące stosunków pracy czy sporów wynikających ze zobowiązań kontraktowych i deliktowych z partnerami gospodarczymi fideikomisu. Drugą kategorię stanowiły sprawy o naruszenie specyficznego statusu dóbr fideikomisowych i ich powiernika (niebędącego właścicielem dóbr). Obejmowały one szeroki katalog problemów, przekraczania uprawnień powiernika względem praw rodziny czy konkretnych „oczekiwaczy”, np. niedozwolony podział, sprzedaż lub użycie dóbr fideikomisowych jako przedmiotu zabezpieczenia, nieprawidłowy zarząd dobrami. Trzecim z zagadnień wymagających zbadania są orzeczenia związane ze sprawami spadkowymi dotyczącymi fideikomisu. Analiza tej problematyki wymaga także uwzględnienia kwestii związanych z prawem rodzinnym i stosunkami rodzinnymi w rodach fideikomisowych, zwłaszcza sprawy ewentualnej opieki nad małoletnimi powiernikami. Zrealizowanie powyższych zadań badawczych pozwoli na sformułowanie ogólnych wniosków na temat funkcjonowania fideikomisów w praktyce orzeczniczej sądów II RP i problemów prawnych z tym związanych, na tle prac ustawodawczych i debat publicznych, zakończonych ostatecznie przyjęciem ustawy likwidującej fideikomisy na ziemiach polskich z $1939 \mathrm{r}$.

Warto zauważyć, że problem prawny funkcjonowania fideikomisów w okresie Drugiej Rzeczypospolitej ma także walor praktyczny w perspektywie współczesnych stosunków prawnych. Dotyczy to w szczególności szeroko pojętych spraw reprywatyzacyjnych obejmujących nieruchomości wchodzące w skład dawnych ordynacji, powiernictw familijnych i tym podobnych instytucji, które unaoczniają do dziś aktualne problemy z interpretacją reguł prawnych rządzących fideikomisami $^{23}$. Kompleksowy projekt badawczy omawiający stan formalnoprawny dotyczący fideikomisów, a jednocześnie wskazujący podstawowe kierunki i problemy $\mathrm{z}$ interpretacją oraz stosowaniem tych przepisów w międzywojennej Polsce - $\mathrm{i}$ to na obszarach czterech odrębnych systemów prawa cywilnego - może okazać się również przydatny we współczesnej praktyce administracyjnej i sądowej.

${ }^{23}$ Por. np. wyrok Naczelnego Sądu Administracyjnego z dnia 28 kwietnia 2016 r., sygn. I OSK 2867/15, Centralna Baza Orzeczeń Sądów Administracyjnych, http://orzeczenia.nsa.gov.pl/doc/069 CE1ACEE [dostęp: 30.04.2019]. 
Prezentowany projekt badawczy stanowi też odpowiedź na niedostatki dotychczasowych badań nad znaczeniem fideikomisów w systemie prawnym Polski w okresie międzywojennym. Prowadzone wcześniej prace w tym zakresie - często bardzo wartościowe - obejmowały raczej standardowe badania nad prawem pozytywnym. Opierały się zatem na analizie formalno-dogmatycznej tekstów prawnych, z uwzględnieniem orzecznictwa ograniczonego głównie, jeśli nie wyłącznie, do Sądu Najwyższego, i tylko w zakresie kluczowych problemów wykładni przepisów. Nie kwestionując wartości takich badań, warto zauważyć, że system prawny Polski przedwojennej jest - w przeciwieństwie do dzisiejszego - niedynamiczny i zamknięty. Dysponujemy całością materiału normatywnego (który nie może już ulec zmianie) oraz szerokim materiałem z zakresu stosowania prawa przez sądy wszystkich szczebli. Daje to wyjątkową z perspektywy współczesnego prawnika (tak teoretyka, jak i praktyka) okazję do analizy materiału w pełni ukształtowanego, który pozwala na ustalenie zamkniętego katalogu istniejących problemów i interpretacji prawnych narosłych wokół nieistniejącej już instytucji prawnej.

Wyjątkowość zakreślonego obszaru badawczego wyraża się także w tym, że przedmiotem analizy objęte zostanie funkcjonowanie podobnych, niemal tożsamych instytucji prawnych w ramach czterech różnych porządków prawnych obowiązujących jednak na obszarze jednego państwa. Jak wcześniej wskazano, systemy te, chociaż hołdujące (poza Zwodem Praw) ideom wspólnym dla XIX-wiecznych kodyfikacji, wykazywały wiele odrębności. Dlatego warto określić, w jakim stopniu te cechy specyficzne rzutowały na stosowanie prawa w praktyce orzeczniczej sądów. Czy pojęcia tożsame były różnie rozumiane w poszczególnych dzielnicach? Czy podobne problemy rozstrzygano w sposób zbliżony, czy zdecydowanie odmiennie? Mozaika prawna okresu Drugiej Rzeczypospolitej stwarza zatem pole dla badaczy, których wyniki badań - zwłaszcza z ostatniego komparatystycznego etapu - mogą zainteresować czytelników także poza granicami Polski.

\section{DOBÓR MATERIAŁU ŹRÓDŁOWEGO}

Realizacja przedstawionych zamierzeń badawczych wymaga szczegółowej analizy czterech kategorii źródeł. Pierwsza to akty prawne regulujące status i funkcjonowanie fideikomisów w poszczególnych dzielnicach porozbiorowych oraz obowiązujących na każdym z tych terenów regulacji ogólnych dotyczące prawa cywilnego materialnego.

W prawie austriackim fideikomisy zostały uregulowane przez kodeks cywilny ABGB z 1811 r. ${ }^{24}$ Procedura zakładania i rozwiązywania fideikomisów została

${ }^{24}$ Część druga [O prawie rzeczowym], Oddział 1 [O prawach ściśle rzeczowych], Rozdział 10 [O dziedzicach podstawionych i powierznictwach (fideikommisach)] ABGB - §§ 618-645. Treść 
natomiast uregulowana $\mathrm{w}$ austriackim patencie procesowym o postępowaniu niespornym z 1854 r. ${ }^{25} \mathrm{~W}$ porządku prawnym Drugiej Rzeszy Niemieckiej istnienie fideikomisów zostało uznane za niesprzeczne z kodeksem cywilnym niemieckim BGB z 1896 r. Na mocy art. 59 ustawy wprowadzającej kodeks utrzymano w mocy normy obowiązujące w tym zakresie w poszczególnych ,państwach związkowych"26. W Prusach problematyka fideikomisowa, zarówno w aspektach prawnomaterialnych, jak i częściowo procesowych, była ujęta w przepisach Pruskiego Prawa Krajowego (Landrechtu Pruskiego z 1794 r.) ${ }^{27}$ oraz w późniejszych ustawach z $1840 \mathrm{i} 1855^{28}$. Uzupełnieniem były wydane po $1918 \mathrm{r}$. akty polskie modyfikujące urządzenia poniemieckie: ustawa $\mathrm{z}$ dnia 18 listopada 1921 r. o dobrach rodzinnych $w$ b. dzielnicy pruskiej ${ }^{29}$ wraz z rozporządzeniem wykonawczym ${ }^{30}$. Status niemieckich fideikomisów w Polsce rozstrzygały w pewnym stopniu bilateralne umowy międzynarodowe z Republiką Weimarską ${ }^{31}$. W odniesieniu do dawnego Królestwa Kongresowego stan formalnoprawny istniał w zasadzie poza Kodeksem Napoleona, wprowadzany szczegółowym ustawodawstwem rosyjskim (m.in. ukazem carskim z 1835 r. o dobrach donacyjnych ${ }^{32}$ ). Na ziemiach wschodnich zakładanie i funkcjonowanie ordynacji regulowały przepisy kodeksowe Zwodu

w języku polskim na podstawie: Powszechna księga ustaw cywilnych dla wszystkich krajów dziedzicznych niemieckich Monarchji austryjackiej: z późniejszemi odnośnemi ustawami i rozporządzeniami, wyd. M. Zatorski, F. Kasperek, Cieszyn 1875, por. literatura z przyp. 11.

${ }^{25}$ Dział IV: O pieczy nad fideikomisem (\$\$ 220-256) Patentu niespornego z 9 sierpnia $1854 \mathrm{r}$. Tekst polski: Postępowanie w sprawach niespornych (patent niesporny) i ustawa o ubezwłasnowolnieniu z 28 I 1916 wraz z orzecznictwem b. sądów austrjackich $i$ sądów polskich, dodatkowymi ustawami i rozporządzeniami polskiemi, oraz okólnikami ministerjalnymi, thum. i oprac A. Laniewski, Lwów 1928, s. 146-163.

${ }^{26}$ Por. popularne w dawnym zaborze pruskim thumaczenie polskie: Niemiecki Kodeks Cywilny wraz z ustawa wprowadzająca, tłum. T. Zborowski, Poznań 1899, s. 604.

27 Regulacje zawarto w Części 2, Tytule 4 [O wspólnych prawach familijnych], w Oddziałach: 3 [O ordynacjach] - §§ 47-133; 4 [O porzadku następstwa w Ordynacjach] - §§ 134-205; 5 [O rozdziale pomiędzy następca $w$ ordynacji $i$ dziedzicami ostatniego posiadacza] - §§ 206-226, por. Powszechne Prawo Krajowe dla Państw Pruskich, t. III, Poznań 1826, s. 258-282.

${ }^{28}$ Prawo o uchwałach familijnych przy fideikomisach familijnych, fundacjach familijnych i lennach z dnia 15 lutego 1840; Uchwała tyczaca się fideikomisów familijnych, substytucyi fideikomisowych i fundacyi familijnych w Xięstwie Szlaskiem i Hrabstwie Kłodzkiem z dnia 15 lutego 1840, „Gesetz-Sammlung für die Königlichen Preussischen Staaten” 1840, nr 3, s. 2070 i 2071; Uchwata dotyczaca kompetencyi władz sadowych $w$ sprawach familijno-fideikomisowych $z$ dnia 5 marca 1855, „Gesetz-Sammlung für die Königlichen Preussischen Staaten” 1855, nr 9, s. 4178.

${ }^{29}$ Dz. U. Nr 100, poz. 715.

${ }^{30}$ Rozporządzenie wykonawcze Ministra Sprawiedliwości z dnia 31 stycznia 1922 r. do ustawy z dnia 18 listopada 1921 r. o dobrach rodzinnych w b. dzielnicy pruskiej (Dz.U. 1922, Nr 14, poz. 129).

31 Układ polsko-niemiecki o dobrach rodzinnych (Dz.U. 1926, Nr 17, poz. 99).

32 Dziennik Praw Królestwa Polskiego, t. XVII, s. 323. 
Praw $^{33}$. Istotne znaczenie miały także akty prawne uchwalone już w Drugiej Rzeczypospolitej wyrażające dążenie do likwidacji fideikomisów. Były to wspomniane już ustawy: z dnia 25 lipca 1919 r. w przedmiocie dóbr donacyjnych; z dnia 18 listopada 1921 r. o dobrach rodzinnych w b. dzielnicy pruskiej, a także z dnia 7 sierpnia 1937 r. o zniesieniu fideikomisu Pszczyńskiego ${ }^{34}$ i wskazywana już kilkakrotnie ustawa o znoszeniu ordynacyj rodowych.

Drugą kategorię źródeł stanowią indywidualno-konkretne akty fundacyjne fideikomisów. Powołanie fideikomisu wymagało czynności prawnej fundatora, który w akcie fundacyjnym określał podstawowe reguły funkcjonowania fideikomisów - uwzględnienie zatem tej kategorii źródeł jest niezbędne do pełnej realizacji planowanych zamierzeń badawczych. Konieczne będzie również przyjrzenie się księgom gruntowym i hipotecznym z czasów zaborów i Drugiej Rzeczypospolitej w celu weryfikacji stanu dóbr poszczególnych fideikomisów.

Trzecia kategoria źródeł - najważniejsza dla opisywanych planów naukowych obejmuje orzeczenia sądów apelacyjnych i okręgowych dotyczące funkcjonowania fideikomisów. Do realizacji przedstawionych zamierzeń badawczych niezbędna będzie analiza wszystkich orzeczeń wydanych w tych sprawach w okresie międzywojennym. Jest to oczywiście zależne od stanu zachowania akt spraw sądowych ${ }^{35}$.

${ }^{33}$ Przepisy dotyczące ordynacji zawiera zwłaszcza Księga druga [O sposobie nabywania i utwierdzania praw do majątków w ogólności]. W jej Dziale I [O różnych rodzajach majątków] art. 392 poświęcono przynależnościom majątku ordynackiego. W ramach Działu II [O istocie $i$ zakresie różnych praw do majątku] w Rozdziale II [O prawie własności niepetnem] regulacje dotyczące ordynacji zostały zawarte w: Oddziale 3 [O prawie własności do ordynacyj dziedzicznych] - art. 467-493, Oddziale 4 [O prawie własności do ordynacyj tymczasowych] - art. 493'-493 $3^{46}$ i Oddziale 5 [O prawie własności majątków nadawanych pod nazwą majoratów w guberniach zachodnich] - art. 494-512. Problematykę ordynacji regulacją także oczywiście przepisy z zakresu prawa spadkowego - w Księdze trzeciej [O trybie nabywania i utwierdzania praw majątkowych w szczególności], Dziale II [O nabywaniu majątków przez spadkobranie ustawowe], w Rozdziale II [O porządku dziedziczenia z mocy ustawy], Oddziale 7 [O szczególnym przypadku dziedziczenia, w przypadkach wyjętych spod przepisów ogólnych] - art. 1192-1217. Tekst regulacji wraz ze wskazaniem nowelizacji i uchyleń dokonanych przez ustawodawstwo polskie: Prawo cywilne ziem wschodnich..., tłum. i oprac. Z. Rymowicz, W. Świecicki, t. 1, s. 141, 265-292, 667-676.

${ }^{34}$ Dz.U. Nr 60, poz. 474.

${ }^{35}$ Stopień zachowania akt sądowych z okresu dwudziestolecia międzywojennego wynika z dwóch powodów. Pierwszym są potencjalne straty w zakresie zasobu archiwalnego w czasie II wojny światowej. Drugi stanowią przepisy archiwalne, które przesądzają o klasyfikacji archiwalnej dokumentacji. Dziś problematykę tę reguluje rozporządzenie Ministra Sprawiedliwości z dnia 5 marca 2004 roku w sprawie przechowywania akt sądowych oraz ich przekazywania lub do zniszczenia (Dz.U. 2014, poz. 991). Stanowi ono potwierdzenie reguł przyjętych w polskiej metodyce i praktyce archiwalnej XX w. Co do zasady w zakresie ważnych dla projektu spraw: cywilnych i gospodarczych oraz z zakresu prawa pracy akta spraw uznaje się za dokumentację niearchiwalną (oznaczoną kategorią archiwalną B) w rozumieniu ustawy o narodowym zasobie archiwalnym i archiwach. Oznacza to, że dokumentacja ta przeznaczona jest do brakowania (niszczenia) po upływie określonego w przepisach czasu. Do kategorii archiwalnej A, czyli dokumentacji przeznaczonej do 
Uzupełnieniem mogą się jednak okazać kopie akt spraw i orzeczeń składowane w archiwach rodzinnych i majątkowych rodów, które zakładały fideikomisy. Naturalnie akta rodowo-majątkowe dóbr fideikomisowych będą pełnić w badaniach na potrzeby projektu znacznie ważniejszą rolę. Zawierają one bowiem szeroko pojętą dokumentację prawną i ekonomiczną sporządzaną i otrzymywaną przez administrację danych dóbr w związku z zarządzaniem nimi i ich eksploatacją gospodarczą. Są to najczęściej bogate zasoby, zawierające liczne jednostki archiwalne. Sięgnięcie do nich pozwoli uzupełnić materiał sądowy, wyjaśniając kontekst analizowanych spraw tam, gdzie nie będzie on w pełni wynikał z akt sądowych. Ta kategoria źródeł ma więc pełnić głównie rolę wyjaśniającą i uzupełniającą, umożliwiając poznanie treści aktów fundacyjnych fideikomisów oraz dokumentów koniecznych do wyjaśnienia kontekstu prawnego i ekonomicznego sporów sądowych ich dotyczących ${ }^{36}$. Wybór materiału został podyktowany przede wszystkim zamierzeniem zbadania problemu funkcjonowania fideikomisów familijnych jako zagadnienia prawnego. Dlatego podstawę badań stanowić będą źródła o charakterze jurydycznym - akty prawne i orzeczenia. Źródła pozwalające ocenić kwestie polityczne, społeczne czy ekonomiczne związane $\mathrm{z}$ istnieniem fideikomisów w międzywojennej Polsce

przekazywania do archiwum państwowego i przechowywania wieczystego, zalicza się tylko pewne kategorie spraw. Chodzi zwłaszcza o sprawy o ochronę praw autorskich i wynalazczych, z zakresu prawa osobowego dotyczących uznania za zmarłego, stwierdzenia zgonu, ubezwłasnowolnienia oraz takich, w których sąd przekazał zagadnienie prawne do Sądu Najwyższego oraz w których wartość przedmiotu sporu w dniu wydania orzeczenia kończącego postępowanie w sprawie 2,5 tysiąca razy przekracza minimalne wynagrodzenie za pracę. Wieczyście przechowuje się również sprawy z rejestru przedsiębiorców, fundacji oraz innych organizacji społecznych i zawodowych $(\S 12$ rozporządzenia). Uznaniowo można zaliczyć do kategorii A również sprawy mające „wyjątkowe” znaczenie ze względu na materiał zebrany w sprawie lub osoby w niej występujące (§§ 12 i 19). Ponadto przepisy nakazują zachowanie wieczyste po jednej sprawie ,typowej” z okresu pięcioletniego do każdego rodzaju spraw przewidzianego w wykazie symboli spraw z danego zakresu ( $§ 13$ i 20). W komplecie przechowuje się wieczyście także repertoria, wykazy akt i skorowidze akt sądowych (§ 22). W konsekwencji przyjęcia tych reguł zachowane akta sądowe spraw dotyczących fideikomisów familijnych muszą być zdekompletowane. Ogólne uwagi dotyczące przepisów regulujących kwalifikowania i brakowania dokumentacji niearchiwalnej z lat 1918-1965 w PRL zawiera szkic M. Tarakanowskiej, Problem brakowania akt w Polsce w świetle przepisów i literatury archiwalnej w latach 1918-1965, „Archeion” 1967, nr 44, s. 43-55.

${ }^{36}$ Charakterystykę archiwalną zachowania ich oraz opracowywania ich treści zawierają liczne studia szczegółowe. Programowe założenie w tym zakresie zawiera artykuł T. Zielińskiej, Archiwalia prywatne (Pojęcie, zakres gromadzenia, metody opracowania), „Archeion” 1971, nr 56, s. 71-88. Autorka ta poświęciła też interesujący szkic zagadnieniu ,zespołowości” w odniesieniu do archiwów rodzinno-majątkowych: Problemy zespołowości archiwaliów rodzinno-majątkowych [w:] H. Robótka (red.), Komputeryzacja archiwów, t. III: Problemy zespołowości w archiwistyce i praktyce archiwów. Materiały sympozjum, Toruń 20 i 21 października 1995 r., Toruń 1997, s. 57-66. Informacje o specyfice archiwalnej takich aktów zawierają też wydane przez Naczelnego Dyrektora Archiwów Państwowych Wskazówki metodyczne do opracowywania archiwów podworskich, https://www.archiwa.gov.pl/files/przepisy_metodyczne/1983_1.pdf [dostęp: 28.03.2019]. 
zostaną uwzględnione tylko o tyle, o ile kontekst pozaprawny będzie konieczny do zrozumienia stanu faktycznego danej sprawy.

\section{ETAPY PRAC}

W celu uporządkowania prowadzonych badań i zoptymalizowania ich wyników za konieczne uznano podzielenie działań na kilka etapów. W pierwszej fazie zasadne wydaje się prowadzenie prac osobno dla każdej z byłych dzielnic Drugiej Rzeczypospolitej: byłego zaboru pruskiego, byłego zaboru austriackiego, dawnej „Kongresówki" oraz tzw. ziem wschodnich. W stosunku do każdego z tych obszarów przeprowadzone zostaną dwa etapy badań: poszukiwawczy i analityczny. Pierwszy etap obejmie kwerendę archiwalną, odnalezienie, zgromadzenie i skopiowanie materiałów. Równolegle podjęte zostaną prace związane z dogmatyką problemu, a więc pełne opracowanie istoty konstrukcji i przemian stanu prawnego fideikomisów w poszczególnych dzielnicach Rzeczypospolitej. Na drugi etap składa się opracowanie materiału według przyjętych w projekcie założeń metodologicznych $\mathrm{i}$ terminologicznych, tj. zgodnego $\mathrm{z}$ warsztatem prawniczym zbadania orzecznictwa dla każdego z omawianych terytoriów. Najistotniejszy powinien być jednak ostatni etap prac o charakterze komparatystycznym, gdzie zebrany wcześniej materiał źródłowy, odpowiednio opracowany i przestudiowany, zostanie poddany krytycznej analizie, ze wskazaniem i oceną podobieństw i różnic w funkcjonowaniu fideikomisów w perspektywie porządku prawnego międzywojennej Polski jako całości.

Realizacja tych zadań badawczych wymaga podjęcia wielu czynności technicznych. W pierwszej kolejności należy utworzyć listę fideikomisów funkcjonujących na obszarze każdej z dzielnic państwa na podstawie archiwalnych akt sądowych i urzędowych, ksiąg gruntowych, akt rodzinno-majątkowych i innych źródeł ${ }^{37}$. Następnie odnaleźć, wyselekcjonować i skopiować wyroki sądów cywilnych dotyczące fideikomisów, wydane przez sądy w Drugiej Rzeczypospolitej na terenach danej dzielnicy (wraz z materiałami ukazującym społeczno-gospodarczy kontekst konkretnej sprawy) oraz zrekonstruować problemy prawne dotyczące fideikomisów i sposoby ich rozstrzygnięcia w świetle zgromadzonego materiału orzeczniczego ${ }^{38}$.

37 Punkt wyjścia stanowić będzie wykaz ordynacji sporządzony przez urzędy wojewódzkie na podstawie ankiet z lat 30. XX w.: Wykaz ordynacyj i fideikomisów sporzadzony w marcu $1936 r$. wedlug prowizorycznych danych urzędów wojewódzkich, Archiwum Państwowe w Poznaniu, Urząd Wojewódzki Poznański (296), sygn. 6171; Załącznik do wykazu ordynacyj i fideikomisów, Archiwum Państwowe w Poznaniu, Urząd Wojewódzki Poznański (296), sygn. 6196. Wzięte pod uwagę zostanie także zestawienie fideikomisów należących do polskich rodów w 1918 r., opracowane przez M. Kozaczkę, Gospodarka ordynacji..., s. 25-26.

${ }^{38}$ Istotnym problemem technicznym, z którym musi się zmierzyć zespół badawczy w ramach podejmowanego projektu jest znaczne rozproszenie polskiej sieci archiwalnej. Przyjęte reguły właś- 


\section{PODSUMOWANIE}

Po niemal rocznej pracy nad tematem można pokusić się o częściowe podsumowanie tego etapu i skonfrontowanie założeń z dotychczasowymi, oczywiście wstępnymi, wynikami pracy.

W dziedzinie dogmatycznej został przygotowany opis istoty konstrukcji i przemian statusu prawnego fideikomisów familijnych w Drugiej Rzeczypospolitej. Opracowania dotyczące każdego z byłych zaborów objęły: źródła prawa (prawo powszechnie obowiązujące, statuty ordynackie); definicja i istota konstrukcji prawnej a konstrukcje pokrewne; tworzenie fideikomisu; podmioty (fundator, powiernik); majątek fideikomisu; czynności prawne; nadzór nad fideikomisem; likwidacja i znoszenie fideikomisu. Jeśli chodzi o czynności techniczne, które wiązały się z dużym wysiłkiem i zaangażowaniem czasowym, to można stwierdzić, że podjęte przez członków zespołu badania różnej proweniencji archiwaliów w Bydgoszczy, Katowicach, Poznaniu, Pszczynie i Warszawie wykazały znaczne zróżnicowanie w dokumentacji dotyczącej opisywanej problematyki badawczej. Okazało się przy tym, że wyjątkowo interesujące informacje związane $\mathrm{z}$ fideikomisami familijnymi znajdują się w dokumentacji Rady Ministrów, Ministerstwa Rolnictwa oraz Głównej Komisji Ziemskiej i Okręgowych Urzędów Ziemskich dotyczących skutków reformy rolnej - przymusowych parcelacji i wykupów majątków wchodzących w skład ordynacji. Wydaje się też, że wiele materiałów będzie można zgromadzić na podstawie dokumentacji dotyczącej mniej znanych ordynacji, np. Czerniejewa czy książąt Radolinów. Istnieje zatem potrzeba intensyfikacji badań archiwalnych w pozostałych ośrodkach.

Dotychczasowe działania zespołu i wstępne wyniki jego pracy wskazują, że początkowe założenia po pierwszym etapie badań mogą ulec istotnej zmianie, a sam temat okaże się dużo obszerniejszy i bardziej skomplikowany. Oznacza to jednak, że także wyniki mogą stać się bardziej interesujące i rzucić nowe światło na zagadnienie fideikomisów familijnych w Drugiej Rzeczypospolitej.

\footnotetext{
ciwości rzeczowej i miejscowej archiwów państwowych w Polsce powodują, że badania materiału sądowego z czasów Drugiej Rzeczypospolitej muszą objąć zakresem kwerendy dwa archiwa centralne (Archiwum Główne Akt Dawnych i Archiwum Akt Nowych) oraz niemal wszystkie archiwa niemające charakteru centralnego wraz z oddziałami. Por. załącznik nr 5 rozporządzenia Ministra Kultury i Dziedzictwa Narodowego z dnia 20 października 2015 r. w sprawie klasyfikowania i kwalifikowania dokumentacji, przekazywania materiałów archiwalnych do archiwów państwowych i brakowania dokumentacji niearchiwalnej (Dz. U. 2015, poz. 1743).
} 


\title{
FAMILY FIDEICOMMISSA IN THE SECOND REPUBLIC OF POLAND - MAIN RESEARCH POSTULATES
}

\begin{abstract}
An article presents assumptions and a summary of an introductory stage of empirical research on family fideicommissa in the Second Republic of Poland. The research was undertaken as a project entitled: "Family fideicommissa in the Second Republic of Poland in the light of civil courts jurisdiction. History of a legal institution from a feudal era in the conduct of legal transactions of a modern state." The main task of the project is to diagnose and fully describe crucial problems of the feudal era relicts (that fideicommissa definitely were) in the reality of modern state in the $20^{\text {th }}$ century. Family fideicommissa created in Polish-Lithuanian Commonwealth, and during so-called Partitions, survived after regaining independence by Poland in 1918. Their existence was regulated by provisions under few legal systems: old-Polish, as well as Prussian, Austro-Hungarian, and Russian (with influences of French civil law, still in force in previous "Congress" Kingdom of Poland). Authors present the hitherto achievements of science in the field of research on fideicommissa, especially legal papers. On the basis of those previous finding (mostly by lawyers from the interwar period), they try to resolve basic dilemmas on definitions, terminology, and legal construction of fideicommissa, that were a result of differentiation of legal systems in the Second Republic. The article is an opportunity to show both, theoretical plans for archive research, as well as practical results of searching accomplished during the first year of work in more than ten archive institutions.
\end{abstract}

Keywords: family fideicommissa, Second Republic of Poland, civil law, history of law, jurisdiction of civil courts 